\title{
AUXOSPORE FORMATION AND THE MORPHOLOGY OF THE INITIAL CELL OF THE MARINE ARAPHID DIATOM GEPHYRIA MEDIA (BACILLARIOPHYCEAE) ${ }^{1}$
}

\author{
Shinya Sato $^{2}$ \\ Department of Ocean Sciences, Tokyo University of Marine Science and Technology, Konan 4-5-7, Minato-ku, Tokyo 108-8477, Japan
} Tamotsu Nagumo

Department of Biology, The Nippon Dental University, Fujimi 1-9-20, Chiyoda-ku, Tokyo 102-8159, Japan

and

\section{Jiro Tanaka}

Department of Ocean Sciences, Tokyo University of Marine Science and Technology, Konan 4-5-7, Minato-ku, Tokyo 108-8477, Japan

Recent studies have led to a rapid increase in knowledge of auxospore formation in diatoms. However, these studies have been limited to centric and raphid pennate diatoms, and there is still very little information for the araphid pennate diatoms. Using LM and SEM, we studied the development of the auxospore and the initial cell of the marine epiphytic diatom Gephyria media Arnott. Auxospores were bipolar and curved in side view, as in many other pennate diatoms. SEM revealed many transverse perizonial bands, all of which were incomplete rings. There was an elongate, sprawling, silicified structure beneath the ventral suture of the transverse perizonial bands. This structure is presumably equivalent to the longitudinal perizonial band in other pennate diatoms, although we could not determine the homologous relationship between the two features. Scales were found both in the inner wall of the perizonium and around the primary perizonial bands. The presence or absence of scales may be of phylogenetic significance in diatoms, only during the final stages of auxospore formation because scales are found in early spherical stages. The distinctive finger-like structures observed throughout all stage of G. media have not been observed before in the other diatom taxa.

Key index words: araphid diatom; auxospore; elongate sprawling structure; finger-like structure; "freeze method"; Gephyria media; initial cell; morphology; perizonium; scale

Gephyria Arnott is an araphid pennate diatom genus whose members grow in marine coastal regions. The genus is characterized by flexed cells that attach to the substratum by mucilaginous pads, which are secreted from the apical pore fields at the poles of the concave

\footnotetext{
${ }^{1}$ Received 8 September 2003. Accepted 28 April 2004.

${ }^{2}$ Author for correspondence: e-mail auxospore@yahoo.co.jp.
}

valve. Because of its flexure and the presence of apical pore fields on the concave valve only, Gephyria is heterovalvate. The arcuate valves have a two-layered construction containing many chambers (Round et al. 1990). The morphological features of $G$. media were described by John (1984). Valve morphogenesis was studied by Tiffany (2002) using LM and SEM. Most diatoms may undergo sexual reproduction when their cell sizes are sufficiently small, after a series of mitotic cell divisions. After sexual reproduction, the zygote (auxospore) expands and an initial cell is formed within it. The evolutionary significance of auxospore structure in all major groups of diatoms is well accepted (Round and Crawford 1981, von Stosch 1982) and recently reconfirmed by Kaczmarska et al. (2000, 2001). For example, the auxospores of most centric diatoms, for example, Ellerbeckia arenaria f. arenaria (Moore ex Ralfs) R. M. Crawford, are covered with large numbers of scales (Schmid and Crawford 2001). However, the auxospores of many species of pennate diatoms, for example, Rhoicosphenia curvata (Kützing) Grunow, are enclosed by a perizonium (Mann 1982b), which is composed of many bands, often in two series, transverse and longitudinal. In Pseudo-nitzschia multiseries (Hasle) Hasle, scales have been observed on the surface of the gametes and the primary auxospore wall (Kaczmarska et al. 2000). Kaczmarska et al. (2000) speculated that scales may prove to be more common when more species are examined.

Knowledge of auxospore formation in diatoms is rapidly increasing (Mann 1982b, Cohn et al. 1989, Mann and Stickle 1989, Mayama 1992, Passy-Tolar and Lowe 1995, Kaczmarska et al. 2000, Kobayashi et al. 2001, Schmid and Crawford 2001, Nagumo 2003). However, this information is limited to studies on centric diatoms and raphid pennate diatoms, and there is still very little information for the araphid diatoms. Auxospore formation has been reported in several araphid diatoms: Grammatophora marina (Lyngbye) Kützing (Magne-Simon 1960, 1962), Rhabdonema adriaticum Kützing (Karsten 1899, von Stosch 1958, 1962), 
R. arcuatum Kützing (Karsten 1899, von Stosch 1962, 1982), R. minutum Kützing (von Stosch 1958), Diatoma Bory, Meridion Agardh and Synedra (Geitler 1973), Striatella unipunctata (Lyngbye) Agardh, Licmophora abbreviata Agardh (Roshchin 1994), and L. ehrenbergii (Kützing) Grunow (Roshchin 1994, Roshchin and Chepurnov 1999), L. gracilis (Ehrenberg) Grunow var. anglica (Kützing) Peragallo (Mann 1982a). However, none of these studies included EM. In our study, several stages in the development of the auxospore and initial cell of Gephyria media were observed using SEM.

\section{MATERIALS AND METHODS}

Vegetative cells and auxospores of G. media attached to Plocamium telfairiae Harvey (Rhodophyceae, Plocamiaceae) were collected by S. Sato from Tenjin-jima, Kanagawa Prefecture, Japan on January 2003. All organic matter, outside and inside the cells, was removed by the bleaching method (Nagumo and Kobayasi 1990) to reveal the silicified valves and associated structures. To observe the initial cell without perizonial bands, "bleached" specimens were cleaned by boiling with concentrated sulfuric acid and potassium nitrate for about $10 \mathrm{~min}$ and then washed several times in distilled water (Patrick and Reimer 1966).

Samples were observed in LM with bright field or differential interference contrast optics. To keep auxospores intact for SEM observation, samples were prepared using a novel method, which we call the "freeze method." Samples were fixed with $10 \%$ glutaraldehyde, rinsed with distilled water until all the glutaraldehyde was removed, frozen in a $-20^{\circ} \mathrm{C}$ freezer, and placed in a vacuum (temperature maintained below freezing point) to allow the sample to sublime until ice was no longer visible. This method reduces labor time and does not require the use of many chemicals.

For SEM observations, dried specimens were placed on a cover glass, which was then fixed to a metal stub with carbon tape and paste. An S-4000 scanning electron microscope (Hitachi, Tokyo, Japan) was used at an accelerating voltage of 3 or $5 \mathrm{kV}$. The morphological terms in this article were taken from Anonymous (1975), Cox and Ross (1981), and, particularly with respect to the auxospores, from Round et al. (1990).

\section{RESULTS}

Auxospore formation. Vegetative cells usually exhibited three copulae per theca (Figs. 1, A-D, and 2A). Before auxospore formation, the number of copulae in the mother cell increased and numerous discoid chloroplasts were visible (Fig. 2B). After expansion of the girdle, the protoplasm contracted toward the center of the cell (Fig. 2, C-E), and the cell comprised one attached valve (concave) and about 20 copulae. By this time, the other convex valve had often been lost (Fig. 2, D and E). After the protoplasm had contracted, the early stage of the auxospore gradually grew away from the mother cell (Fig. 2, $\mathrm{F}-\mathrm{J}$ ), and the auxospore became covered with a mucilage envelope. The swelling of the auxospore ruptured some copulae (Fig. $2 \mathrm{H}$ ), which were subsequently lost (Figs. 2, I and J, and 4, C and D). As the auxospore emerged from the mother cell, perizonial bands began to form at the center of the auxospore (Fig. 2J, arrowhead).
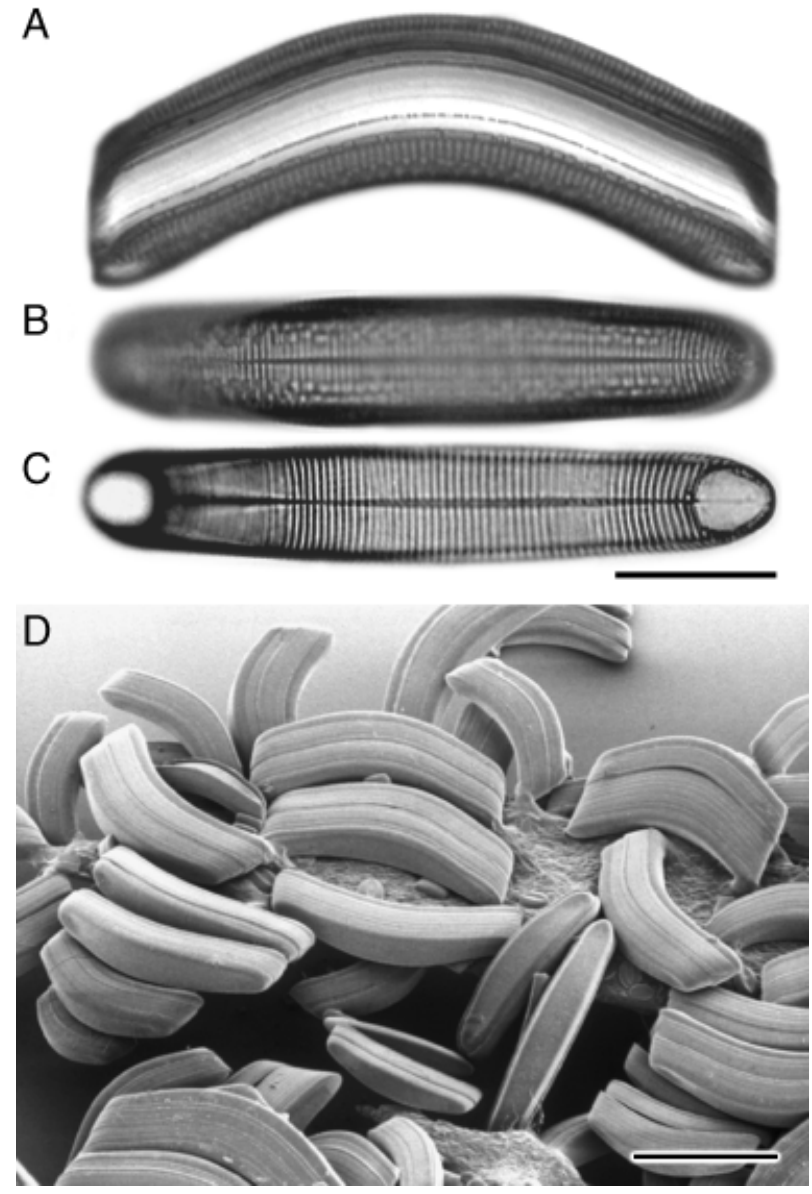

FIG. 1. Vegetative cells of Gephyria media with LM (A-C) and SEM (D). Scale bars: $30 \mu \mathrm{m}(\mathrm{A}-\mathrm{C})$ or $10 \mu \mathrm{m}$ (D). (A) Girdle view of a cleaned frustule. (B) Valve view of the convex valve. (C) Valve view of the concave valve. (D) Colony on Plocamium telfairiae Harvey. Note that frustules are always attached by their concave valves to the host seaweed or another cell.

Meanwhile, many of the chloroplasts contracted toward the ventral side (Fig. 2, H-J). The number of the perizonial bands then increased, although perizonial caps were still attached at both ends of the auxospore (Figs. 3, A and C, and 4D, double arrowhead). At this stage of auxospore formation, there were about 20 perizonial bands, and no special structure was observed on the ventral side (Fig. 3A). This central part of the ventral side formed a suture. The suture resulted from the fact that all the transverse perizonial bands were incomplete hoops, their open ends lying on the ventral side of auxospore. Subsequently, an elongate sprawling structure was formed beneath the suture (Fig. 3, B and C) on the ventral side, expanding until the auxospore had matured. When the auxospore reached its maximum size, it had a large number (approximately 60) of perizonial bands (Figs. 3C and 4). Formation of the initial epivalve commenced as soon as the auxospore reached its maximum size (Fig. 4B). After the initial epivalve had been completed, the initial hypovalve started to form (Fig. 4C, arrow). The 


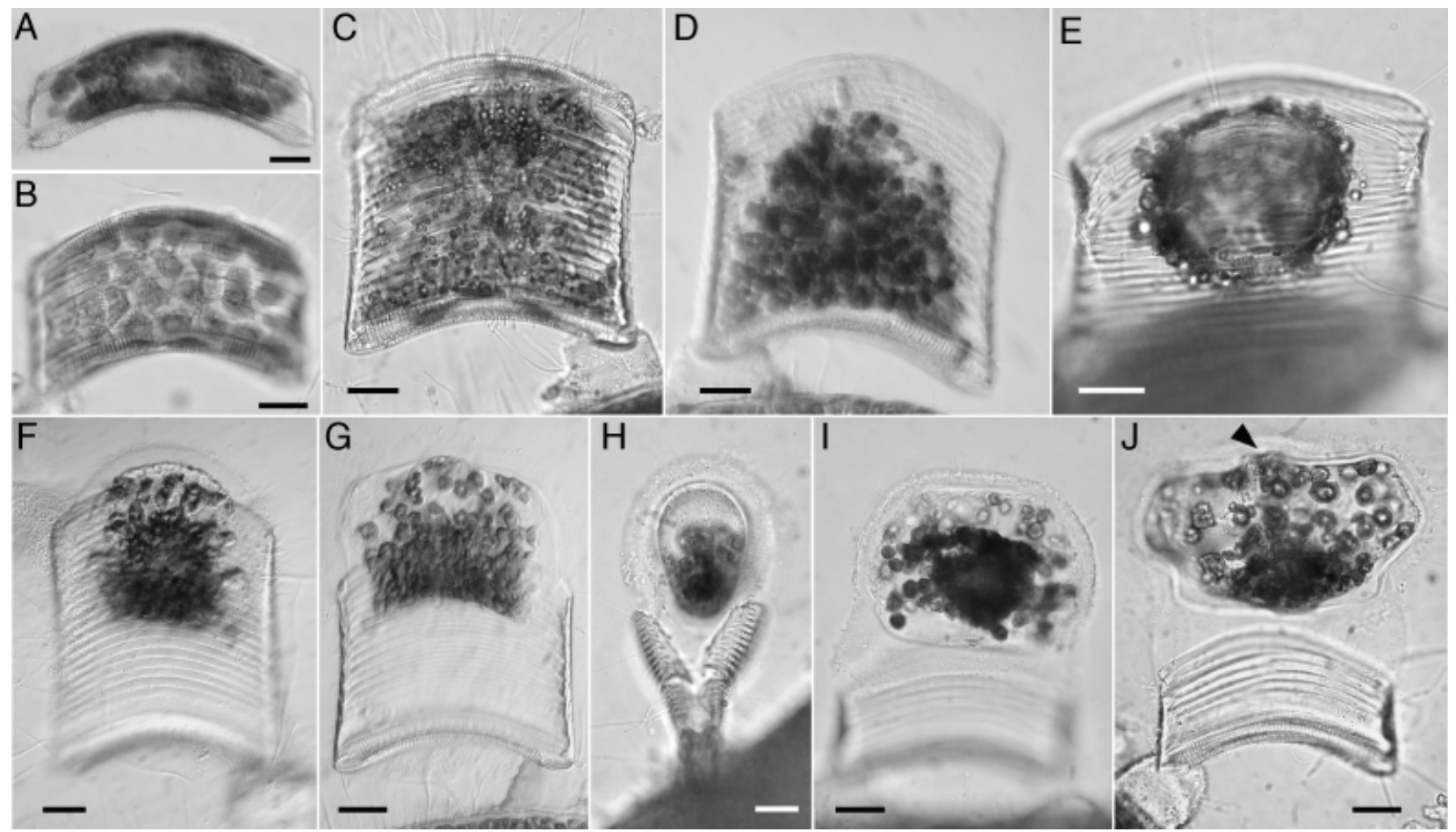

FIG. 2. Auxospore formation in Gephyria media under LM (A-G, I, J, girdle view; H, apical view). Scale bars, $10 \mu \mathrm{m}$. (A) Vegetative cell in girdle view. (B) Auxospore mother cell. Frustule girdle is deeper than in the vegetative cell and has an increased number of copulae. (C) Approximately twenty copulae in the wall. (D) Protoplasm starts to contract at the center of cell. Note that the nonattached (convex) theca is absent. (E) Protoplasm contraction complete. (F) Protoplast starts growing away from the mother cell. (G) Protoplast just emerging from the mother cell. (H) Copulae are broken by the auxospore as it swells. (I) Early stage of auxospore development. Note that the broken copulae have already disappeared. (J) Auxospore begins to increase the number of perizonial bands (arrowhead).

mature auxospore, enclosing the complete initial cell, remained associated with the mother cell by mucilaginous substances (Fig. 4, C and D, between two arrowheads). By this stage, the perizonial caps had sometimes been lost but otherwise adhered to the ends of the auxospore (Fig. 4D, double arrowhead). We did not observe any evidence of male gametangia, fertilization, or autogamy in the present study.

Fine structure of the auxospore. SEM observation of the auxospore mother cell confirmed that it had numerous copulae (Fig. 5A), each of which was perforated by a row of areolae (Fig. 5B). The copulae were of the open type, with open and closed ends alternating at each pole (Fig. 5C). The perizonium consisted of a large number of perizonial bands (Fig. 5D), which were all open (Fig. 5E), including the primary band (not shown). The bands were closely associated with each other (Fig. 5F), and their fimbriate margins were slightly longer at the pars interior than the pars exterior (Fig. 5G). In external view, the center of suture was covered with a fragment similar to a perizonial band (Fig. $5 \mathrm{H}$, arrow). In internal view, an elongate sprawling structure was observed on the ventral side of the auxospore. The structure extended in a longitudinal direction but was simpler in form than the perizonial band (Fig. 5, I and J). As the auxospore became longer, the elongate sprawling structure expanded transversely along the suture (Fig. 3, B and C).
Simple circular to elliptic scales, $5-15 \mu \mathrm{m}$ in diameter, were observed against the inner wall of the auxospore (Fig. 6). The scales possessed a central boss without areolae surrounded by a fimbriate margin (Fig. 6, A, B, D, and E). The distribution of the scales differed from that in previously studied diatoms, because they were scattered throughout the perizonium (Fig. 6B) as well as over the inner and outer surfaces of the primary perizonial band (Fig. 6, C-E).

Initial cell. The length of the initial cell was about twice that of the mother cell (Fig. 4, C and D). Valves usually had an abnormal outline (Fig. 7, A and B), and the striae on the initial hypovalve were sometimes irregularly arranged (Fig. 7C). There were two rows of pores between each pair of virgae (biseriate striae) at the margin of the initial valve (Fig. 7D), whereas, according to John (1984), Round et al. (1990), and Tiffany (2002), vegetative valves have triseriate striae at their margins. Notably, the density of striae was different between the initial convex valve $(13-14$ in $10 \mu \mathrm{m})$ and the initial concave valve $(12-13$ in $10 \mu \mathrm{m})$ and from the vegetative convex valve $(14-15$ in $10 \mu \mathrm{m})$ and the vegetative concave valve $(11 \mathrm{in} 10 \mu \mathrm{m})$ (measured at the center of valve with SEM).

In the internal view of valve, many elliptic openings were seen (Fig. 7E, arrowheads). A rimoportula was observed at the apex of the initial epivalve (Fig. 7E, 


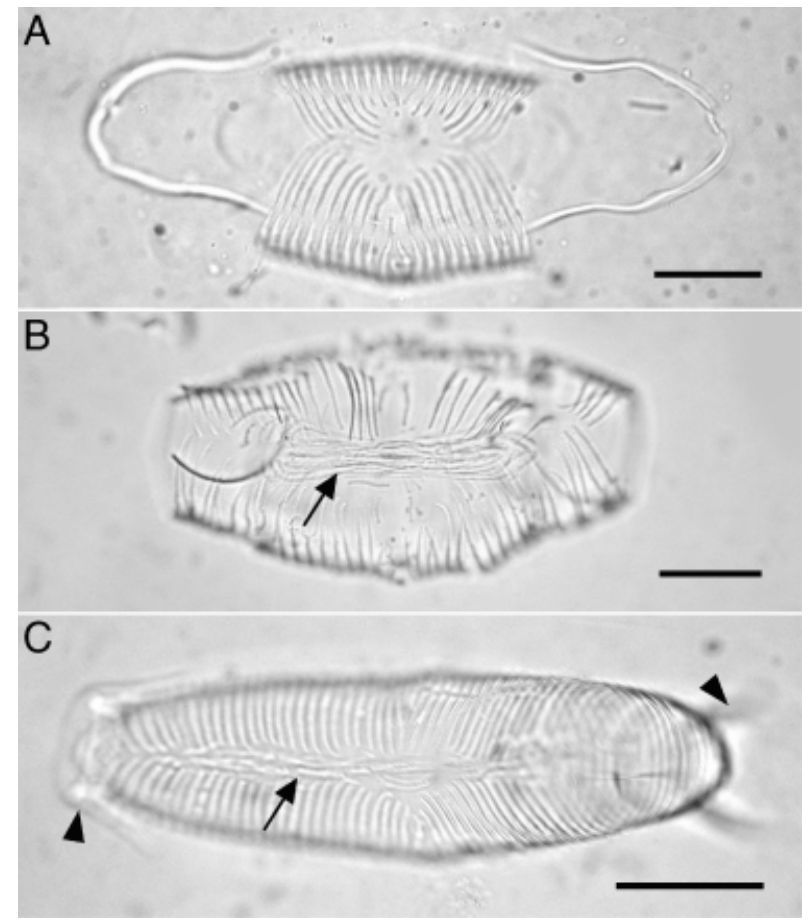

FIG. 3. Ventral view of three stages of auxospore development in Gephyria media under LM. Scale bars: $20 \mu \mathrm{m}$ (A and B) or $50 \mu \mathrm{m}(\mathrm{C})$. (A) Perizonium caps at both ends; no structure is observed under the suture. (B) Elongate sprawling structures present at suture (arrow). (C) Elongate sprawling structures longitudinally extended at suture (arrow): inside out perizonium caps (left arrowhead) and inside out cap (right arrowhead).

arrow). The position of the rimoportula on the vegetative valve was beneath the apical pore field; on the other hand, that of initial convex valve was located much further $(\mathrm{ca} .10 \mu \mathrm{m})$ the valve apex (John 1984, Tiffany 2002). Finger-like structures were found on the initial epi- and hypovalve (Fig. 7, F-H) of G. media. These structures could be seen through external areola opening (Fig. 7F), and the internal view showed that they wound themselves around the vimines (Fig. 7, G and H). Tiffany (2002, Figs. 13 and 14) concluded that these structures were fine rotae. However, rotae occlude the pores in two dimensions (e.g. Triceratium shadboltianum Greville) rather than in three dimensions as seen in G. media. The finger-like structures observed throughout all stage of $G$. media are distinctive and have never been observed in the other diatom taxa.

\section{DISCUSSION}

Auxospore formation and perizonium morphology. The production of additional copulae by the auxospore mother cell has been observed in a few other diatoms, both centric (e.g. Arachnoidiscus ornatus Ehrenberg; Kobayashi et al. 2001) and pennate (e.g. Rhabdonema adriaticum; Karsten 1899). There are also some parallels with Arachnoidiscus even though the convex valve of the mother cell is lost in Gephyria and the
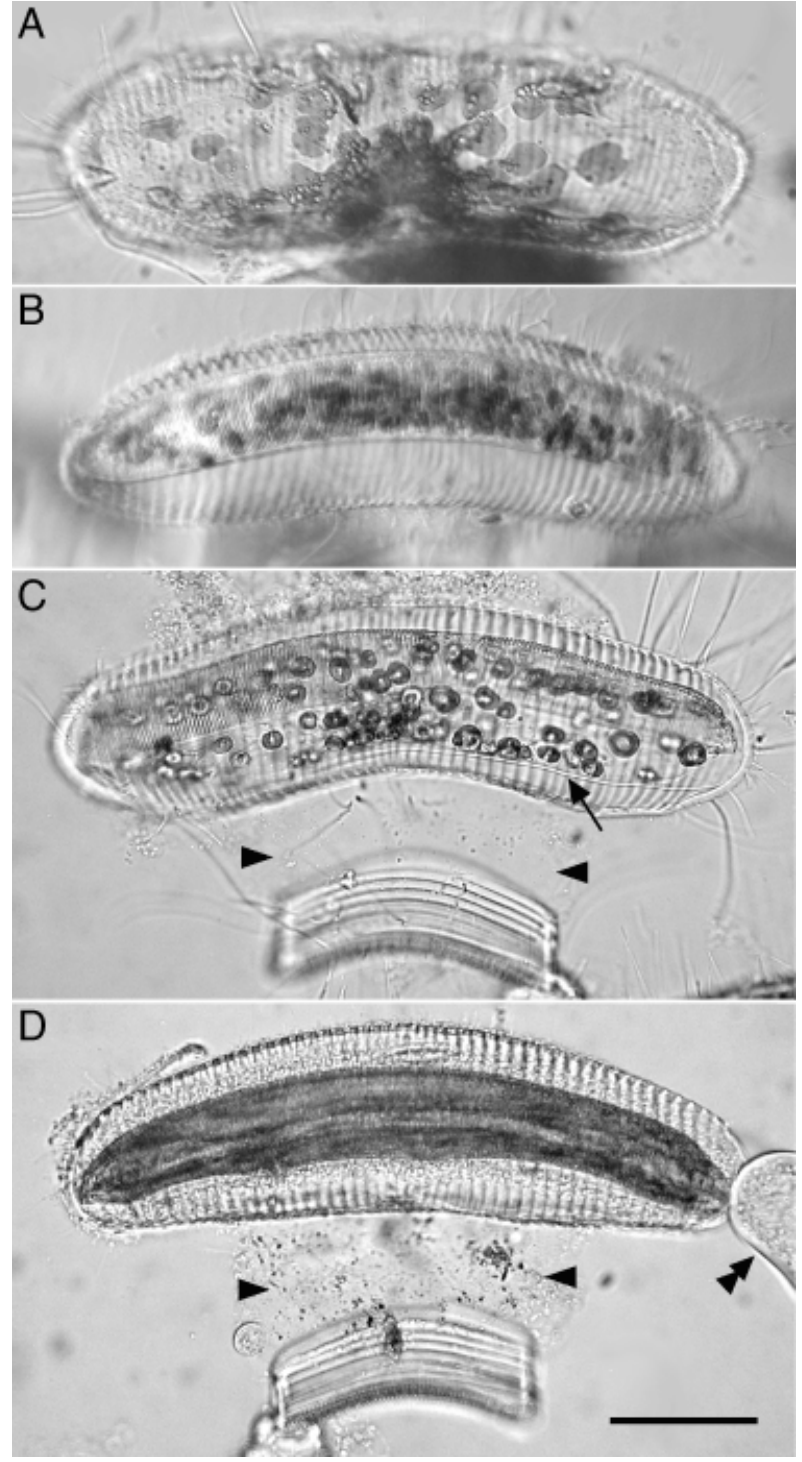

FIG. 4. Four stages of initial cell formation (girdle view) in the expanded auxospore under LM. Scale bars, $50 \mu \mathrm{m}$. (A) Most chloroplasts contracted close to the ventral side. (B) Initial epivalve in auxospore. Many chloroplasts inside the epivalve. (C) Initial hypovalve (arrow) forming in auxospore. Chloroplasts are now distributed throughout the initial cell. Arrowheads indicate mucilaginous material connecting the auxospore and its mother cell. (D) Complete initial cell in auxospore with perizonial cap (double arrowhead). Mucilaginous material present (between the arrowheads).

nonattached valve of Arachnoidiscus remains on its auxospore. Both taxa are haterovalvate, epiphytic, and relatively large cells. They were often observed together on the same substratum, for example, Gelidium elegans Kützing (Rhodophyceae, Gelidiales) and Plocamium telfairiae in our material. Further information is required, however, to determine the phylogenetic relationships between these two taxa.

Perizonial caps derived from the zygote wall of G. media differed in thickness from those of some 

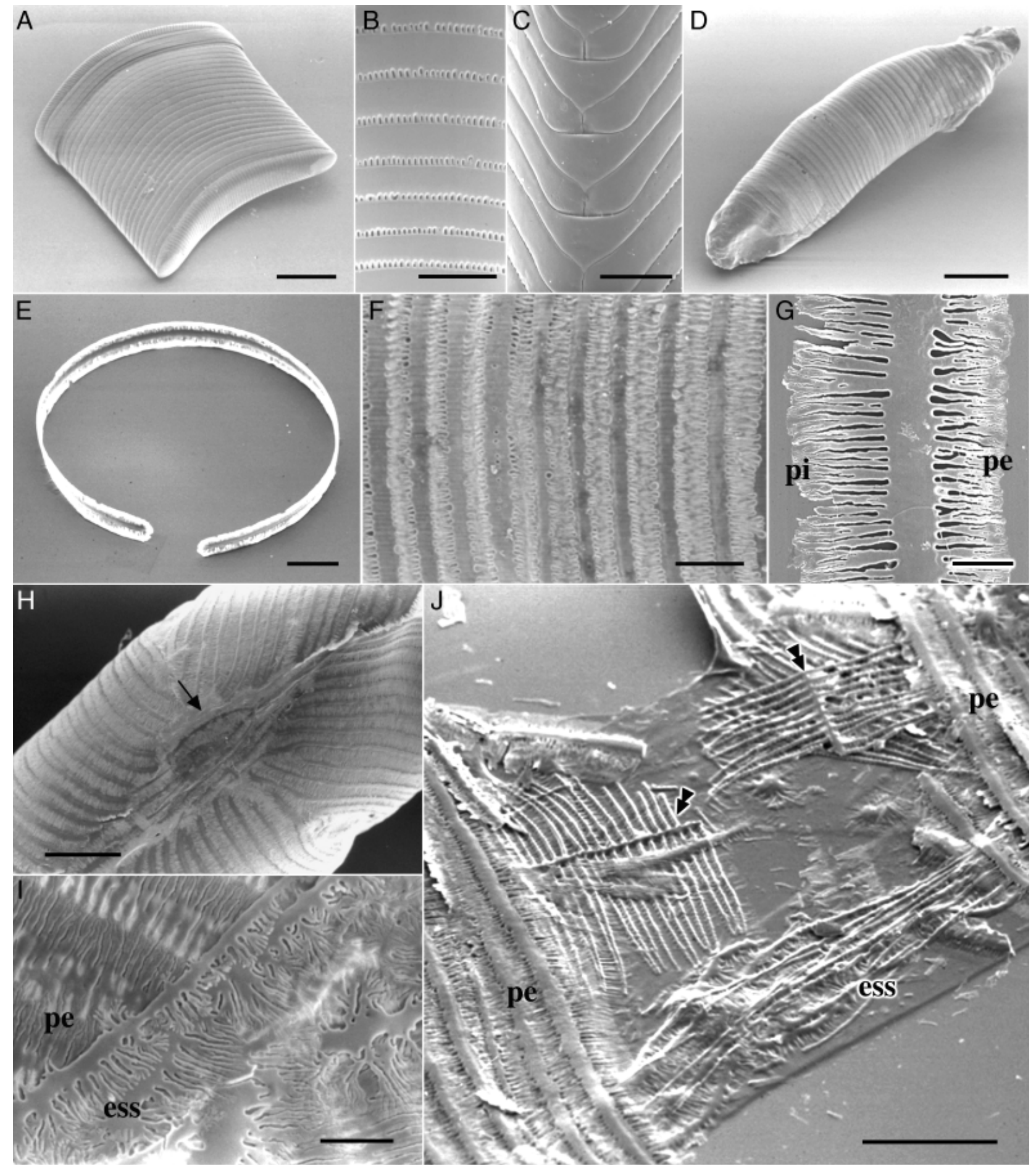

FIG. 5. Fine structure of auxospore mother cell and perizonium with SEM. Scale bars: $30 \mu \mathrm{m}(\mathrm{A}, \mathrm{J}), 10 \mu \mathrm{m}(\mathrm{B}, \mathrm{C}, \mathrm{E}, \mathrm{F}, \mathrm{H}), 50 \mu \mathrm{m}(\mathrm{D})$, or $5 \mu \mathrm{m}(\mathrm{G})$. (A) Oblique view of auxospore mother cell with increase number of copulae. (B) Row of areolae on copulae of auxospore mother cell (external). (C) Apical view of the mother cell (external) showing overlapping copulae. (D) Oblique view of mature perizonium comprising numerous perizonial bands. (E) Split ring type of perizonial band. (F) Perizonial bands closely associated with each other. (G) Enlargement of perizonial band. Note the asymmetry of the fimbriate margins. Fimbriate margin of pars interior (pi) is longer than that of pars exterior (pe). (H) Elongate sprawling structures at the ventral suture. Arrow indicates a somewhat elliptic structure at the center. (I) Internal view of perizonium (pe) and the elongate sprawling structure (ess) at the ventral suture. (J) Separated perizonial components, showing the elongate sprawling structure (ess) in the perizonium (pe). Double arrowheads indicate fragments of the forming initial valve within the perizonium. 

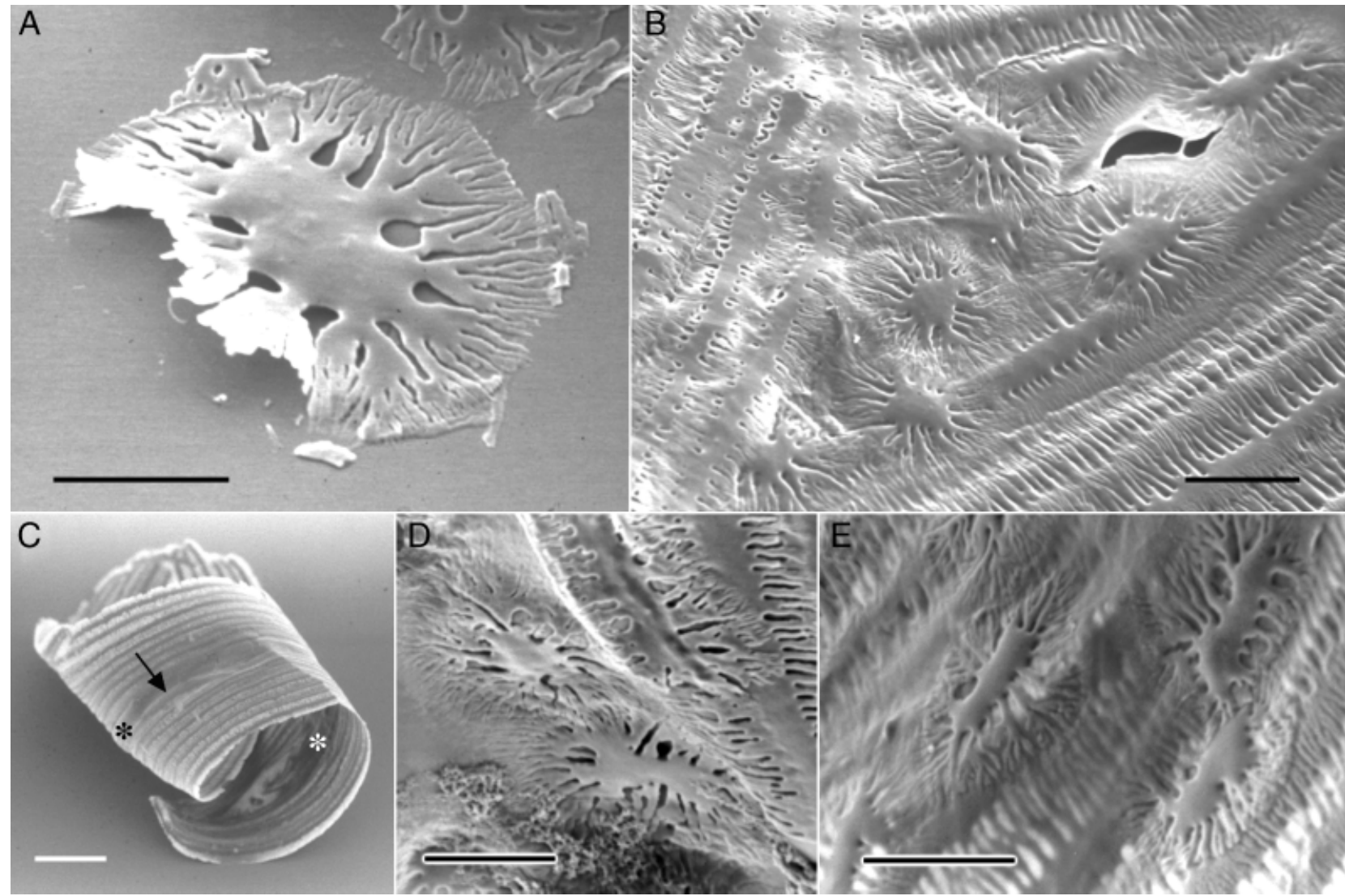

Fig. 6. Scales on perizonium under SEM. Scale bars: $3 \mu \mathrm{m}$ (A), $5 \mu \mathrm{m}$ (B, D, E), or $20 \mu \mathrm{m}$ (C). (A) Oblique view of a scale. (B) Disrupted and deflated perizonium showing scales on inner wall. (C) Oblique view of portion of a disrupted perizonium. Arrow indicates primary perizonial band. (D) Enlargement of the part marked with a black asterisk in C. Scales on the outer surface of the primary perizonial band. (E) Enlargement of the part marked with a white asterisk in C. Scales on the inner surface of primary perizonial band.

raphid diatoms, for example, Frustulia rhomboides (Ehrenberg) De Toni var. saxonica (Rabenhorst) De Toni (Pfitzer 1871), Neidium affine (Ehrenberg) Pfitzer (Mann 1984), and Seminavis cf. robusta Danielidis and D. G. Mann (Chepurnov et al. 2002). When auxospore expansion is completed, most of the perizonial caps of G. media turn inside out (Figs. 3C, arrowhead, double arrowhead, and 4D, double arrowhead) and then are lost. The perizonium caps of $N$. affine contain a high proportion of silica and regulate the size of transverse perizonial bands formation (Mann 1984). The perizonial caps of $G$. media are presumably made by organic matter judging by its softness (easily turn inside out) and surface texture under SEM (not shown), which was rough, unlike that of $N$. affine. Therefore, we regard the perizonium caps of G. media as remnants on the auxospore without any active role.

The primary band of $G$. media could only be distinguished by its position. This is different from raphid pennate diatoms, in which the primary perizonial band often differs from the other bands and may be a closed hoop, for example, Amphora copulata (Kützing) Schoeman and Archbald (Nagumo 2003), Craticula cuspidata Kützing (Cohn et al. 1989), Navicula oblonga (Kützing) Kützing (Mann and Stickle 1989), N. affine (Mann
1984), and R. curvata (Mann 1982b). The secondary and the tertiary bands are distinguishable in width. The secondary bands are narrower than the tertiary bands (Fig. 5D), which is similar to that observed in Gomphoneis mesta Passy-Tolar and Lowe (Passy-Tolar and Lowe 1995) and R. curvata (Mann 1982b).

In general, diatoms construct their siliceous structures exquisitely and precisely, as exemplified by the regularity of scales, perizonia, and the valve striae. On the other hand, the elongate sprawling structure beneath the ventral suture in Gephyria is formed quickly and is relatively simple and irregular in shape. The elongate sprawling structure shows obvious similarities to the longitudinal perizonial band of $R$. arcuatum (von Stosch 1982, their Figs. 1 and 4c). Both structures are narrow in width and lie beneath the suture. Although the longitudinal perizonial band in $R$. arcuatum is a single structure, the elongate sprawling structure of G. media consists of multiple silicated fragments (Fig. 5, I and J). Furthermore, they are distinguished from each other by the presence or absence of apparent axial sternum. There are also clear differences in shape between the longitudinal perizonial band of many raphid diatoms and the elongate sprawling structure. The longitudinal perizonial band is often broader in width (e.g. 

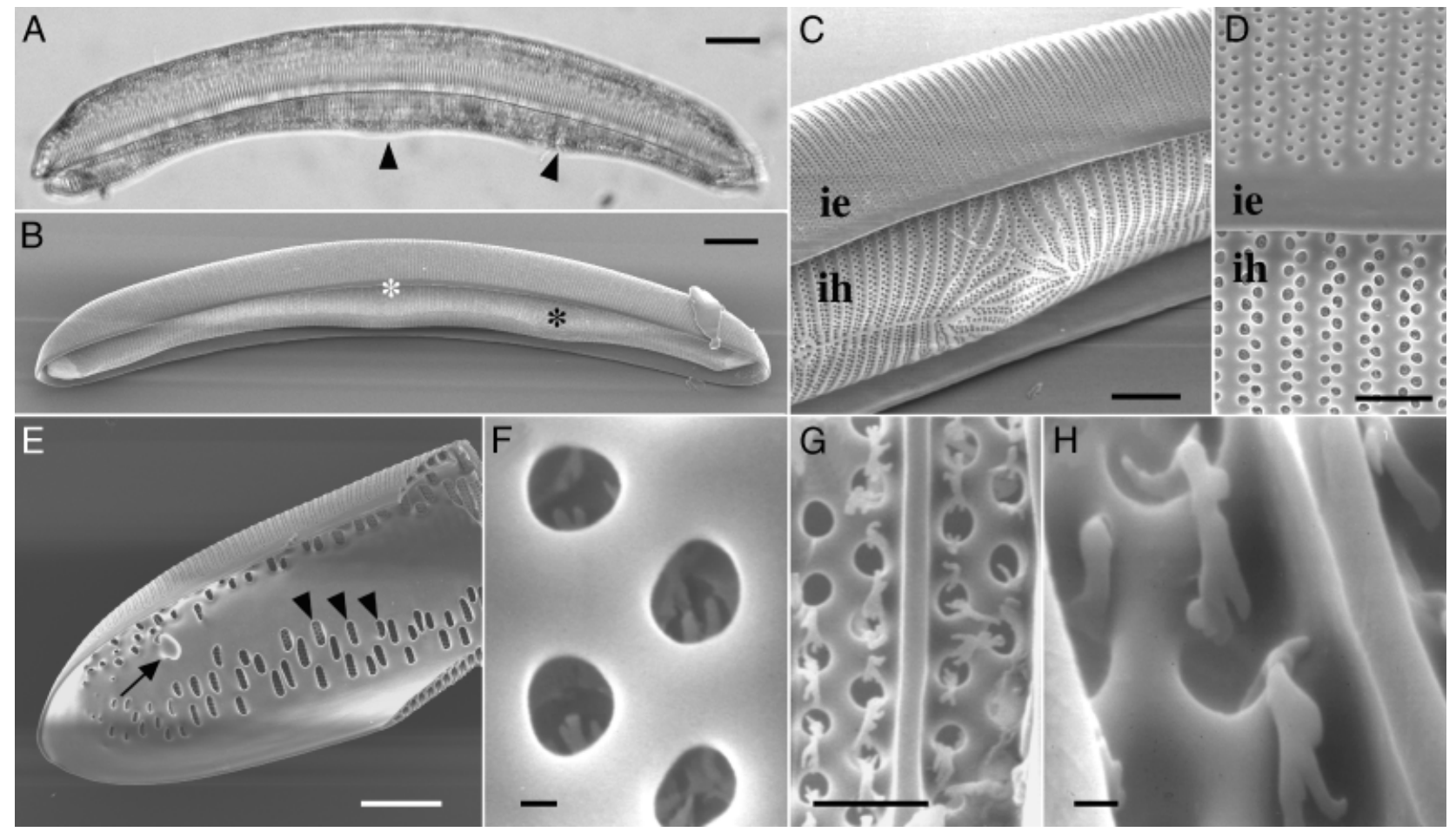

Fig. 7. Initial cells under LM (A) and SEM (B-H). Scale bars: $10 \mu \mathrm{m}(\mathrm{A}, \mathrm{B}, \mathrm{E}), 5 \mu \mathrm{m}(\mathrm{C}), 3 \mu \mathrm{m}(\mathrm{D}), 1 \mu \mathrm{m}(\mathrm{G})$, or $0.1 \mu \mathrm{m}(\mathrm{F}, \mathrm{H})$. (A) Initial cell removed from perizonium. Arrowheads indicate the abnormal shape of the initial hypovalve. (B) Oblique view of initial cell shown in A. (C) Enlargement of the part marked with a black asterisk in B showing initial epivalve (ie) and initial hypovalve (ih). Note the irregular arrangement of striae at initial hypovalve. (D) Enlargement of the part marked with a white asterisk in B. Note the stria density differs between the initial epi- (ie) and hypovalve (ih). (E) Internal view of initial epivalve. Arrow indicates the rimoportula near the valve apex. Arrowheads indicate chamber openings. (F) External view of initial epivalve. Note the finger-like structures are visible through the areola openings. $(\mathrm{G})$ Internal view of initial epivalve. $(\mathrm{H})$ Finger-like structures winding over the vimines.

Navicula ulvacea [Berkeley ex Kützing] Cleve; Mann 1994, Fig. 47A) and highly silicated (e.g. Achnanthes yaquinensis McIntire and Reimer [Toyoda et al. 2003], A. copulata [Nagumo 2003], Diploneis papula [Schmidt] Cleve [Idei 1993], and R. curvata [Mann 1982b]). Both the elongate sprawling structure and longitudinal perizonial band may play an important role in strengthening the auxospore wall in the longitudinal direction and reinforcement of the part of the suture. However, although these structures appear to play similar roles, we cannot assume that they are homologous.

Scale. Scales were found around the primary band and on the inner wall of the perizonium. We speculate that the early stages of the auxospore wall may be covered with scales for protection, like the postulated scale-bearing ancestor of the diatoms (Round and Crawford 1981, Round et al. 1990). Our interpretation of scale distribution on the perizonium wall of G. media is as follows: 10 early stages of the auxospore bear the scales, 2) the auxospore becomes larger and forms many perizonial bands, and 3) the scales are conveyed to both ends as the auxospore expands, although some scales remain at its equator. However, we cannot yet explain why scales were found at the inside of the perizonium.

It is likely that discoid scales are adequate for covering a spherical body, for example, on the gametes and primary auxospore wall in the pennate diatom Pseudonitzschia multiseries (Kaczmarska et al. 2000). However, band-like structures, rather than scales, may be required to cover a tubular structure. Therefore, when and where scales form depends on the morphological features of the auxospore. Further detailed study may reveal that the auxospores of other pennate diatoms bear scales, particularly during the spherical phase and/or on rounded surfaces of the cylindrical body.

This work was supported in part by Grant-in-Aid no. 15570087 from the Ministry of Education, Science, Sports and Culture, Japan. We thank Akiyoshi Takahashi and Jin Bo (Phycological Laboratory at Tokyo University of Marine Science and Technology, Tokyo, Japan) for their assistance with the collection of samples at the Tenjin-jima. We thank Adrian Stotto (Laboratory of Fish Culture at Tokyo University of Marine Science and Technology, Tokyo, Japan) for improving the English. We are grateful to David G. Mann (Royal Botanic Garden, Edinburgh, U. K.) for discussion and comments on the manuscript.

Anonymous. 1975. Proposals for a standardization of diatom terminology and diagnoses. Nova Hedw. Beih. 53:323-54.

Chepurnov, V. A., Mann, D. G., Vyverman, W., Sabbe, K. \& Danielidis, D. B. 2002. Sexual reproduction, mating system, and protoplast dynamics of Seminavis (Bacillariophyceae). J. Phycol. 38:1004-19. 
Cohn, S. A., Spurck, T. P., Pickett-Heaps, J. D. \& Edger, L. A. 1989. Perizonium and initial valve formation in the diatom Navicula cuspidata (Bacillariophyceae). J. Phycol. 25:15-26.

Cox, E. J. \& Ross, R. 1981. The striae of pinnate diatoms. In Ross, R. [Ed.] Proceedings of the 6th International Diatom Symposium on Recent and Fossil Diatoms. O. Koeltz, Koenigstein, pp. 267-78.

Geitler, L. 1973. Auxosporenbildung und Systematik bei pennaten Diatomeen und die Cytologie von Cocconeis-Sippen. Österreich. Botan. Zeitschr. 122:299-321.

Idei, M. 1993. Diploneis papula (A. Schmidt) Cleve. In Hori, T. [Ed.] An Illustrated Atlas of the Life History of Algae. Vol. 3. Unicellular and Fragellated Algae. Utida Rokakuho Publishing, Tokyo, pp. 284-5. (in Japanese).

John, J. 1984. Observation on the ultrastructure of Gephyria media W. Arnott. In Richard M. [Ed.] Proceedings of the 8th International Diatom Symposium. Koeltz Scientific Books, Koenigstein, pp. $155-162$

Kaczmarska, I., Bates, S. S., Ehrman, J. M. \& Léger, C. 2000. Fine structure of the gamete, auxospore and initial cell in the pennate diatom Pseudo-nitzschia multiseries (Bacillariophyta). Nova Hedw. 71:337-57.

Kaczmarska, I., Ehrman, J. M. \& Bates, S. S. 2001. A review of auxospore structure, ontogeny and diatom phylogeny. In Economou-Amilli, A. [Ed.] Proceedings of the 16th International Diatom Symposium. University of Athens, Greece, pp. 153-68.

Karsten, G. 1899. Die Diatomeen der Kieler Bucht. Wiss. Meeresunters. 4:17-205.

Kobayashi, A., Osada, K., Nagumo, T. \& Tanaka, J. 2001. An auxospore of Arachnoidiscus ornatus Ehrenberg. In EconomouAmilli, A. [Ed.] Proceedings of the 16th International Diatom Symposium. University of Athens, Greece, pp. 197-204.

Magne-Simon, M. F. 1960. Note sur le processus de l'auxosporulation chez une diatoméen marine, Grammatophora marina (Lyngb.) Kütz. C. R. Acad. Sci., Paris. 251:3040-2.

Magne-Simon, M. F. 1962. L'auxosporulation chez Tabellariacée marine, Grammatophora marina (Lyngb.) Kütz. (Diatomacée). Cahiers Biol. Mar. 3:79-89.

Mann, D. G. 1982a. Auxospore formation in Licmophora (Bacillariophyta). Plant Syst. Evol. 139:289-94.

Mann, D. G. 1982b. Structure, life history and systematics of Rhoicosphenia (Bacillariophyta). II. Auxospore formation and perizonium structure of Rh. curvata. J. Phycol. 18:264-74.

Mann, D. G. 1984. Auxospore formation and development in $\mathrm{Ne}$ idium (Bacillariophyta). Br. Phycol. J. 19:319-31.

Mann, D. G. 1994. Auxospore formation, reproductive plasticity and cell structure in Navicula ulvacea and the resurrection of the genus Dickieia (Bacillariophyta). Eur. J. Phycol. 29: $141-57$.
Mann, D. G. \& Stickle, A. J. 1989. Meiosis, nuclear cyclosis, and auxospore formation in Navicula sensu stricto (Bacillariophyta). Br. Phycol. J. 24:167-81.

Mayama, S. 1992. Morphology of Eunotia multiplastidica sp. nov. (Bacillariophyceae) examined throughout the life cycle. Korean J. Phycol. 7:45-54.

Nagumo, T. 2003. Taxonomic studies of the subgenus Amphora Cleve of the genus Amphora (Bacillariophyceae) in Japan. Biblioth. Diatomol. 49:1-265.

Nagumo, T. \& Kobayasi, H. 1990. The bleaching method for gently loosening and cleaning a single diatom frustule. Diatom 5:45-50.

Passy-Tolar, S. I. \& Lowe, R. L. 1995. Gomphoneis mesta (Bacillariophyta). II. Morphology of the initial frustules and perizonium ultrastructure with some inferences about diatom evolution. J. Phycol. 31:447-56.

Patrick, R. \& Reimer, C. W. 1966. The Diatoms of the United States. Vol. 1. Monogr. Acad. Nat. Sci., Philadelphia, 13: 1-688.

Pfitzer, E. 1871. Untersuchungen über Bau und Entwicklung der Bacillriaceen. Botanische Abhandlungen aus dem Gebiet der Morphologie und Physiologie. Heft 2, Bonn, 183 pp.

Roshchin, A. M. 1994. Zhiznennye tsikly diatomorykh vodoroslej. Naukova Dumka, Kiev, 170 pp.

Roshchin, A. M. \& Chepurnov, V. A. 1999. Dioecy and monoecy in the pennate diatoms (with reference to the centric taxa). In Mayama, S. Idei, M. \& Koizumi, I. [Eds.] Proceedings of the 14th International Diatom Symposium. Koeltz Scientific Books, Koenigstein, pp. 197-204

Round, E. F. \& Crawford, R. M. 1981. The lines of evolution of the Bacillariophyta. I. Origin. Proc. R. Soc. Lond. B 211:237-60.

Round, F. E., Crawford, R. M. \& Mann, D. G. 1990. The Diatoms: Biology and Morphology of the Genera. Cambridge University Press, Cambridge, 747 pp.

Schmid, A. M. \& Crawford, R. M. 2001. Ellerbeckia arenaria (Bacillariophyceae): formation of auxospores and initial cells. Eur.J. Phycol. 36:307-20.

Tiffany, M. A. 2002. Valve morphogenesis in the marine araphid diatom Gephyria media (Bacillariophyceae). Diat. Res. 17:391-400.

Toyoda, K., Tanaka, J. \& Nagumo, T. 2003. Morphological Features of Vegetative and Initial Cells of Achnanthes yaquinensis McIntire and Reimer (Bacillariophyceae). Third European Phycological Congress, Belfast, Abstract, p. 94.

von Stosch, H. A. 1958. Kann die oogame Araphidee Rhabdonema adriaticum als Bindeglied zwischen den beiden grosssen Diatomeengruppen angesehen werden? Ber. dt. Bot. Ges. 71:241-9.

von Stosch, H. A. 1962. Uber das Perizonium der Diatomeen. Vortr. Gesamt. Botan. 1:43-52.

von Stosch, H. A. 1982. On auxospore envelopes in diatoms. Bacillaria 5:127-56. 